\title{
POLYPROPYLENE FIBERS FILLED WITH CARBON NANOTUBES: MECHANICAL PROPERTIES AND BIOCOMPATIBILITY
}

\author{
Yu.I. Sementsov ${ }^{1 *}$, G.P. Prikhod'ko ${ }^{1}$, N.T. Kartel $^{1}$, T.A. Aleksyeyeva ${ }^{2}$, M.V. Tsebrenko ${ }^{3}$ \\ ${ }^{1}$ Chuiko Institute of Surface Chemistry of National Academy of Sciences of Ukraine \\ 17 General Naumov Str., Kyiv, 03164, Ukraine \\ ${ }^{2}$ Kurdyumov Institute of Metallophysics of National Academy of Sciences of Ukraine \\ 36 Vernadsky Blvd., Kyiv, 03142, Ukraine \\ ${ }^{3}$ Kyiv National University of Technology and Design \\ 2 Nemirovich-Danchenko Str., Kyiv, 01011, Ukraine
}

There have been investigated the process of generating polypropylene fibers filled with carbon nanotubes, their mechanical properties and biocompatibility. It has been found that the increase in the content of carbon nanotubes in the fibers of PP-CNTs increases the viscosity of the melt and reduces the elasticity. Biocompatibility testing of the fiber of PP-BHT showed a nonmonotonic effect of the content of tubes for compatibility of the polymer matrix with living tissues. It has been revealed that the composite with CNT concentration of $1.0 \mathrm{wt} . \%$ causes the least disturbance of the living organism and the tissue reaction to the implant has a local aseptic character.

\section{INTRODUCTION}

One of actual directions of polypropylene (PP) application is production of fibers that in particular are used as suture materials in surgery. For today in greater part the imported materials are applied in Ukraine. The domestically produced PP fibers are remaining of poor quality. Therefore an important question is not only to create the fibers with high mechanical state (characteristics) but, also, to research their compatibility with a living body [1-3].

\section{EXPERIMENTAL}

Multiwalled carbon nanotubes (CNT (Fig. 1) obtained by catalytic pyrolysis are described in [4-5]. For synthesis ferruginous catalyst was used obtained by coprecipitation of aluminium, magnesium, and ferrous iron hydroxides. CNT with average diameter of $10-20 \mathrm{~nm}$ were prepared in a $24 \mathrm{dm}^{3}$ reactor with stirring the catalytic layer by reactor rotation. Propylene obtained after propanol dehydration was used as a source of carbon. Optimum level of propylene conversion to carbon was about $80-97 \%$. Catalysts in process were mixed with progenies silica grade A300 to prevent CNT agglomeration. CNT were obtained as a powder with bulk density of $24-35 \mathrm{~g} / \mathrm{dm}^{3}$ and mass content $80-94 \%$ (residual is catalysts and $\mathrm{SiO}_{2}$ ). Specific surface of purified CNT with ash less than $1 \%$ evaluated by argon desorption was $200-400 \mathrm{~m}^{2} / \mathrm{g}$. Structural parameters of CNT and composite PP-CNT were obtained by transmission microscopy (JEM-100CXII) and X-ray diffraction method (DRON-3M, $\lambda_{\mathrm{Co}}=0.179 \mathrm{~nm}$ ). The flux of isotactic PP grade 21060 TU 05-1756-78 with CNT, its mass fraction was $0.05 \ldots 5.0 \%$ mass., mixed with a combined worm-disk extruder LGP-25 at speed $50 \mathrm{rot} / \mathrm{min}$. Due to significant tensile stress that arises between mobile and fixed disks, the dispensing of CNT in polymer is improved. Initial samples of nanocomposite were obtained as granules. Further for study granules were chipped and pressed at $180^{\circ} \mathrm{C}$ and $5 \mathrm{MPa}$ and stretched out into fibers.

Viscosity ( $\eta$ ) fluxes of initial PP and system PP-CNT were determined by method of capillary viscosimetry on a CF-2 microfluidimeter in the range of fracture stress $\tau=(0.1-5.7) \cdot 10^{4} \mathrm{~Pa}$ at different temperatures $(\mathrm{T})-190,210$, and $220^{\circ} \mathrm{C}$. Elastic properties of nanocomposites were evaluated by swelling data B according method [7]. Guaranteed experimental error of determination of $\eta$ and $\mathrm{B}$ was $\pm(2 \div 5) \%$. The behavior of flow $\eta$ was characterized by the largest slope of the tangent at a curve's given point to the reaches to the axis of abscissas. The 
capability of the melt to the longitudinal strain was assessed by the maximum value of spinning draft $\left(\mathrm{F}_{\max }\right)$ with a guaranteed accuracy of $\pm 7 \%$.
Rupture test was conducted on a $2167-\mathrm{P} 50$ fiber tensile machine. Fibers have been recorded by winding on cylindrical latches. Load rate was $10 \mathrm{~mm} / \mathrm{min}$ for lateral deformation.
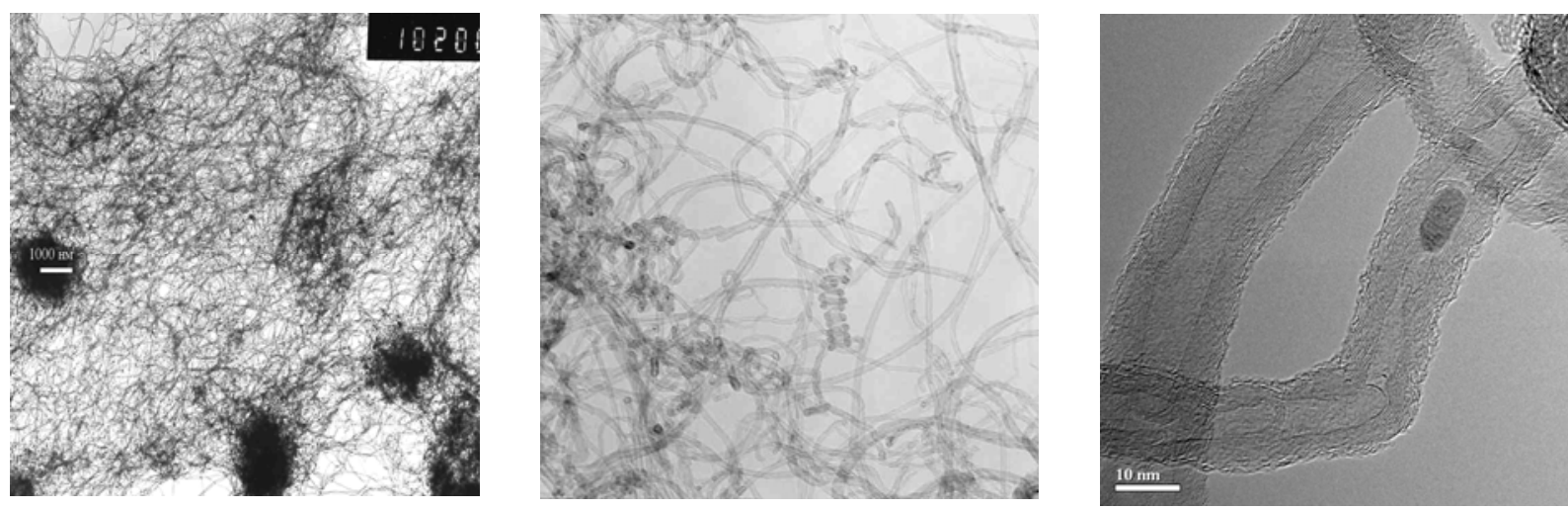

Fig. 1. TEM of samples multiwalled CNT obtained ever $\mathrm{Al}_{3} \mathrm{FeMo}_{0.21}$ catalysts

\section{RESULTS AND DISCUSSION}

Mechanical properties of $P P$ - CNT fibers. It is known that PP is one of the most environmentally friendly and biologically inert polymers. Therefore, one of the areas of its application is the use as suture material in surgery in the form of thin fibers and filaments. In order to working out procedures for obtaining fibers, there were investigated rheological properties of PP-CNT system melts, which showed viscosity increase with increasing CNT content (Table 1).

This result agrees with the conclusion that nanoscale additives determine thixotropic effect of solidification, which leads to an increase in polymers melt viscosity [8]. For compositions with low CNT concentration $(0.05 \div 0.10$ wt. \%) the increase in $\eta$ is small and within the error coincides with the effective viscosity $\left(\eta_{E}\right)$ calculated by Einstein's formula for dilute suspensions:

$$
\eta_{\mathrm{E}}=\eta_{0}(1+2.5 \mathrm{~F}),
$$

where $\eta_{0}$ is viscosity of the medium, $F-$ volume concentration of suspended particles.

The nature of flow characteristics of initial and modified melts does not depend on CNT content for all investigated temperatures and is described by a power function. As expected, the elasticity of melts compositions decreases with increasing concentration of CNT, as evidenced by decreasing value of swelling extrudes (Table 1).
Table 1. Effect of CNT content on the rheological properties of PP-CNT melts

\begin{tabular}{|c|c|c|c|c|c|}
\hline \multirow{2}{*}{$\begin{array}{c}\text { Concentra- } \\
\text { tion, } \\
\text { wt. } \%\end{array}$} & \multicolumn{2}{|c|}{$\eta^{*}, \mathbf{P a} \cdot \mathbf{s}$} & \multirow[b]{2}{*}{ n* } & \multirow[b]{2}{*}{ B* } & \multirow[b]{2}{*}{$\mathbf{F}_{\max }, \mathbf{\%}^{*}$} \\
\hline & $\boldsymbol{\eta}_{\text {exp }}$ & $\boldsymbol{\eta}_{\mathbf{E}}$ & & & \\
\hline 0 & 300 & - & 1.8 & 2.1 & 18000 \\
\hline 0.05 & 305 & 300 & 1.8 & 1.6 & 22000 \\
\hline 0.10 & 315 & 301 & 1.8 & 1.6 & 27000 \\
\hline 0.50 & 350 & 302 & 1.9 & 1.6 & 29000 \\
\hline 1.00 & 450 & 305 & 1.9 & 1.5 & 21000 \\
\hline 5.00 & 480 & 323 & 1.9 & 1.4 & 15000 \\
\hline
\end{tabular}

It is common for filled polymers and associated with reduced flexibility chains of macromolecules. Important scientific and practical result is to improve the capability of molten PP, modified with CNT, for longitudinal deformation: maximum possible spinning draft increases when CNT is added up to $1.0 \mathrm{wt} \%$ that is due to the strengthening of melt flush by increasing viscosity (Table 1 ). The deterioration of melt mixture elastic properties is connected with the $\mathrm{F}_{\max }$ descending with increasing CNT concentration up to $5 \mathrm{wt} \%$.

Thin fibers with diameter $0.09 \mathrm{~mm}$ were produced from the initial PP and composites PPCNT containing CNT 0.5 and 1.0 wt. \%. Test results on the break filaments: averages disruptive force $\left(\mathrm{P}_{\mathrm{f}}\right)$, breaking stress $\left(\sigma_{\mathrm{b}}\right)$, breaking elongation (deformation) $\left(\delta_{\mathrm{v}}\right)$ and their standard deviation (SD) are given in the Table 2. The strength decreasing for tensile deformation and fracture was found for thin fibers at 
0.5 wt. \% CNT concentration. However, at $1.0 \%$ weight concentration the effort and stress fracture of the composite exceed the following values as for the initial $\mathrm{PP}$ and for composite PP $-0.5 \%$ CNT. This effectively reduces the strain to fracture values for pure PP.

The most interesting of these results is that the samples containing CNT become more homogeneous: SD and relative SD properties have significantly lower values for samples containing CNT those for than initial PP samples. So due to the structure forming properties of CNT, the composites defects are decreased. The strength parameters obtained for PP-CNT fibers in comparison with strength characteristics of imported sutures are represented in Table 3. The fibers of the PP$1.0 \%$ CNT with values fracture stress $423 \mathrm{MPa}$ at $20 \%$ elongation are quite a decent place among imported ones.

Table 2. Characteristics of tensile strength for the initial PP and systems PP-CNT

\begin{tabular}{|c|c|c|c|c|c|c|c|c|c|}
\hline $\begin{array}{l}\text { CNT Concentra- } \\
\text { tion, mass. } \%\end{array}$ & $\mathbf{P}_{\mathrm{f} .}, \mathbf{N}$ & SD $P_{f}, \mathbf{N}$ & $\begin{array}{c}\text { Relative SD } \\
\mathbf{P}_{\mathrm{f}}, \% \\
\end{array}$ & $\sigma_{\mathrm{b} .}, \mathbf{M P a}$ & $\begin{array}{c}\text { SD } \sigma_{b .}, \\
\text { MPa }\end{array}$ & $\begin{array}{c}\text { Relative SD } \\
\sigma_{b}, \% \\
\end{array}$ & $\delta_{v}, \%$ & $\begin{array}{c}\text { SD } \boldsymbol{\delta}_{\mathrm{v}}, \\
\%\end{array}$ & $\begin{array}{c}\text { Relative SD } \\
\delta_{\mathrm{v},} \% \\
\end{array}$ \\
\hline 0 & 2.35 & 0.58 & 24.8 & 413.9 & 103 & 24.88 & 20.5 & 6.8 & 33.3 \\
\hline 0.5 & 2.0 & 0.22 & 10.8 & 353.2 & 38.36 & 10.86 & 15.8 & 1.8 & 11.7 \\
\hline 1.0 & 2.4 & 0.28 & 11.6 & 423.4 & 49.3 & 11.64 & 19.8 & 3.6 & 18.2 \\
\hline
\end{tabular}

Table 3. Mechanical properties of suture material used in surgery

\begin{tabular}{lcccc}
\hline \multicolumn{1}{c}{ Type of fiber } & Diameter, mm & $\begin{array}{c}\text { Breaking force, } \\
\text { N }\end{array}$ & $\begin{array}{c}\text { Breaking } \\
\text { elongation, \% }\end{array}$ & $\begin{array}{c}\text { Breaking } \\
\text { stress, MPa }\end{array}$ \\
\hline PROLENE blue 5.0 (1 metric) & 0.14 & 5.89 & 25.4 & 381 \\
PROLENE clear monofilament Polypropylene & 0.14 & 6.78 & 32.5 & 440 \\
Suture 5-0 (1.0 metric) & & & \\
4-0 SURGILENE (1.5 metric) Blue & 0.19 & 11.06 & 30.3 & 391 \\
Monofilament Polypropylene & & & \\
SILK black 4-0 (1.5 metric) & 0.19 & 12.63 & 14.1 & 446 \\
PDS II (polydioanone) Clear monofilament 4/0 & 0.19 & 19.32 & 76.4 & 683 \\
1.5 metric & & & \\
PP+1\% PHHH (Polypropylene Golnit) & 0.19 & 3.75 & 22.1 & 133 \\
PP+1\% PHHH (Polypropylene Golnit) & 0.27 & 17.04 & 12.6 & 298 \\
ETHILON blue Monofilament polyamide 4 & 0.49 & 64.6 & 73.9 & 344 \\
metric & & & & \\
\hline
\end{tabular}

\section{Biocompatibility of composite materials of} PP-CNT system. Biocompatibility of nanocomposite samples was determined by the method described in [9]. Samples were implanted to back muscles of experimental animals. In order to obtain certain results and to reduce the number of animals in the experiment, four composite samples PP-CNT with different CNT concentration were implanted to animals. After four weeks samples excised together with surrounding tissues for subsequent histological studies of tissues and for samples surface investigation. The content of CNT in the polymer matrix nonmonotonously affects on its compatible properties with living tissues. The above-stated is confirmed by the data in the Table 4, which show that the smallest thickness of fibrous connective capsule (as an indicator of the degree of body response to a foreign material) around the implant was the smallest in the case of sample PP-CNT with CNT content 1 wt. $\%$.

Also, the degree of living body response was determined via changes in biochemical blood parameters: glucose, C-reactive protein, and cholesterol. Results of animals' blood serum biochemical analysis show that in glucose and Creactive protein significantly increased day after surgery (Table 5). These figures are typical of post-operative period and indicate that the animal organism responses to intervention.

After 4 weeks, all three parameters are practically indistinguishable from the original values. This indicates that tissues' response to implants has a local aseptic character. The difference is the thickness of fibrous connective 
capsule formed around the sample depends on its surface chemistry. According to preliminary data, nanocomposite with the concentration of carbon nanotubes at $1 \mathrm{wt} . \%$, before the percolation transition in the PP-CNT system [3], causes the smallest influence on a living organism.

Table 4. The thickness of fibrous connective capsule around nanocomposite PP-CNT

\begin{tabular}{ccc}
\hline Sample & CNT concentration, wt. $\%$ & Thickness of capsule, $\boldsymbol{\mu m}$ \\
\hline 1 & 0.05 & $59 \pm 13$ \\
2 & 1.0 & $32 \pm 5$ \\
3 & 3.0 & $72 \pm 15$ \\
4 & 5.0 & $153 \pm 25$ \\
\hline
\end{tabular}

Table 5. Changes of biochemical parameters of blood serum samples during implantation of composite materials

\begin{tabular}{cccc}
\hline Parameter & Before operation & 1 day after operation & 4 weeks after operation \\
\hline Glucose & $5.3 \pm 0.52 \mathrm{~g} / \mathrm{dl}$ & $17.6 \pm 2.8 \mathrm{~g} / \mathrm{dl}$ & $6.1 \pm 0.37 \mathrm{~g} / \mathrm{dl}$ \\
C-reactive protein & $2.4 \pm 0.09 \mathrm{mg} / 1$ & $16.2 \pm 4.1 \mathrm{mg} / 1$ & $3.8 \pm 0.12 \mathrm{mg} / 1$ \\
Cholesterol & $36 \pm 4.8 \mathrm{mM} / 1$ & No data & $42 \pm 12.1 \mathrm{mM} / 1$ \\
\hline
\end{tabular}

\section{CONCLUSIONS}

The inclusion of small quantities ( 1 wt. \%)of CNT to PP matrix increases the mechanical strength and uniformity of fibers on these properties, changes the state of the composite surface and affect on its compatibility to the living body.

\section{REFERENCES}

1. Sementsov Yu., Gavriluk N., Aleksyeyeva T., Lasarenko $O$. Polymer nanocomposites filled of multiwall carbon nanotubes for medical application // Nanosystems, nanomaterials, nanotechnologies. - 2007. - V. 5, N 2. P. 351-360.

2. Sementsov Yu., Gavriluk N., Prikhod'ko G. et al. Biocompatibility of Multiwall CNT and Nanocomposites on the Base of Polymers // Carbon Nanomaterials in Clean Energy Hydrogen Systems. NATO Science for Peace and Security Series C: Environmental Security / Baranowski B., Zaginaichenko S., Schur D., Skorokhod V., Veziroglu A. (Eds.). - Springer Science + Bussines Media B.V., 2008. - P. 327-334.

3. Sementsov Yu.I, Prikhod'ko G.P., Melezhek A.V. et al. Physicochemical properties and biocompatibility of polymer/carbon nanotubes composites. // Nanomaterials and Supramolecular Structure / Shpak A.P., Gorbyk P.P. (Eds.). - Springer Science + Bussines Media B.V., 2009. - P. 347-368.
4. Pat. 69292 A UA, C01B 31/00. Method of carbon nanotubes production / Yanchenko V.V., Sementsov Yu., Melezhyk A.V. - 16.08.04.

5. Melezhek O.V., Sementsov Yu.I., Yanchenko $V . V$. Synthesis of thin carbon nanotubes by copricipitation of metal oxide catalysts // J. Appl. Chem. - 2005. - V.78. - iss.6. P. 938-944 (in Russian).

6. Sementsov Yu.I., Melezhek O.V., Prikhod'ko G.P. et al. Synthesis, structure, physicochemical properties of nanocarbon materials // Shpak A.P., Gorbyk P.P. (Eds) Physical chemistry on nanomaterials and supramolecular structures. - V. 2. - Kyiv: Naukova dumka, 2007. - P. 116-158.

7. Utracki L.A., Bakerdjiane Z., Kamal M.R. A method for the measurement of the true die swell of polymer melts // J. Appl. Polymer Sci. - 1975. - V. 19, N 2. - P. 481-501.

8. Sokolov YA, Shubanov SM, Kandyrin LB, Kalugin EV. Polymer nanocomposites // Struct. Properties Plast. - 2009. - N 3. P. 18-23.

9. Sumer M., Muglali M., Bodrumlu E. et al. Reactions of connective tissue to amalgam, intermediate restorative material, mineral trioxide aggregate, and mineral trioxide aggregate mixed with chlorhexidine // J. Endodontics. - 2006. V. 32. - P. 1094-1096.

Received 01.10.2012, accepted 25.02.2013 


\title{
Волокна поліпропілену, наповненого вуглецевими нанотрубками: механічні характеристики та біосумісність
}

\author{
Ю.І. Семенцов, Г.П. Приходько, М.Т. Картель, Т.А. Алєксєєва, М.В. Цебренко \\ Інститут хімії поверхні ім. О.О. Чуйка Національної академії наук Украӥни \\ вул. Генерала Наумова, 17, Київ,03164, Україна, ysementsov@ukr.net \\ Інститут металофізики ім. Г.В. Курдюмова НАН Украйни \\ бул. Вернадського, 36, Київ, 03142, Україна \\ Київський начіональний університет технологій та дизайну \\ вул. Немировича-Данченка, 2, Київ, 01011, Украӥна
}

\begin{abstract}
Досліджено процеси формування волокон поліпропілену, наповненого вуглещевими нанотрубками (ВНT), їхні механічні характеристики та біосумісність. Встановлено, щзо зростання вмісту вуглецевих нанотрубок у волокнах системи ПП-ВНТ приводить до збільшення в'язкості їхнього розплаву та зменшення еластичності. Тестування біосумісності волокон системи ПП-ВНТ показало немонотонний вплив вмісту трубок на сумісність полімерної матриці з живими тканинами. Виявлено, що композит з концентрацією ВНТ близько 1.0 мас. \% викликає найменше збурення живого організму, а реакиія тканин на імплантати має місиевий асептичний характер.
\end{abstract}

\section{Волокна полипропилена, наполненного углеродными нанотрубками: механические характеристики и биосовместимость}

\author{
Ю.И. Семенцов, Г.П. Приходько, Н.Т. Картель, Т.А. Алексеева, М.В. Цебренко
}

Институт химии поверхности им. А.А. Чуйко Национальной академии наук Украины ул. Генерала Наумова, 17, Киев, 03164, Украина, уsementsov@ukr.net

Институт металлофизики им. Г.В. Курдюмова НАН Украинь

бул. Вернадского, 36, Киев, 03142, Украина

Киевский национальный университет технологий и дизайна ул. Немировича-Данченко, 2, Киев, 01011, Украина

Исследованы процессы формирования волокон полипропилена, наполненного углеродными нанотрубками, их механические характеристики и биосовместимость. Установлено, что рост содержания углеродных нанотрубок в волокнах системы ПП-УНТ приводит к увеличению вязкости их расплава и уменьшению эластичности. Тестирование биосовместимости волокон системы ПП-ВНТ показало немонотонное влияние содержания трубок на совместимость полимерной матрицы с живыми тканями. Выявлено, что композит с концентрацией УНТ около 1.0 мас.\% вызывает наименьшее возмущение живого организма, а реакиия тканей на имплантаты имеет местный асептический характер. 